\title{
Lymphocyte Transformation Induced by Autologous Cells: Stimulation by Cultured Lymphoblast Lines
}

\author{
Marc E. Weksler and Gary Birnbaum \\ From the Division of Allergy and Immunology, Department of Medicine and the \\ Department of Neurology, Cornell University Medical College, New York 10021
}

\begin{abstract}
A в S T R A C T The ability of cultured lymphoblasts to stimulate autologous lymphocyte transformation in "oneway" mixed leukocyte culture has been studied. Intact, cultured lymphoblasts required physical contact with responding lymphocytes to induce transformation. In quantitative terms, lymphocytes incorporate as much thymidine when mixed with irradiated cultured lymphoblasts as they do in response to phytohemagglutinin. The stimulation of lymphocyte transformation by allogeneic cultured lymphoblasts did not parallel the stimulation of lymphocyte transformation by leukocytes from the donor of the lymphoblast culture. The stimulatory determinants on the cultured lymphoblast are unaffected by neuraminidase but destroyed by trypsin. The trypsin-treated cultured lymphoblasts regain their capacity to stimulate autologous lymphocyte transformation within $48 \mathrm{hr}$ in culture. Cultured lymphoblasts possess concanavalin A binding sites. Concanavalin A inhibits the capacity of cultured lymphoblasts to stimulate autologous lymphocyte transformation. The relevance of these findings to EB virus infection of cultured lymphoblasts and to immume surveillance is discussed.
\end{abstract}

\section{INTRODUCTION}

Continuous cultures of lymphoblastic cells may be derived from patients with leukemia and lymphoma (1), infectious mononucleosis (2), and from healthy volunteers (3). Allogeneic cultured lymphoblasts stimulate lymphocyte transformation in mixed culture more than do allogeneic leukocytes (4). Several investigators have found that cultured lymphoblasts from healthy subjects

A portion of this work was presented at the Annual Meeting of the American Society for Clinical Investigation. Atlantic City, N. J., 1971. J. Clin. Invest. 50: 97a.

Dr. Birnbaum is a Post-doctoral Fellow of the National Multiple Sclerosis Society.

Received for publication 18 May 1972 and in revised form 22 August 1972. stimulate autologous lymphocyte transformation in mixed leukocyte culture (5-9). The explanation for this stimulation of autologous lymphocyte transformation is not known. The present study explored the conditions necessary for the stimulation of lymphocyte transformation by autologous cultured lymphoblasts. Further, it was demonstrated that the capacity of cultured lymphoblasts to stimulate allogeneic lymphocyte transformation was not attributable solely to the determinants on lymphocytes that generate the mixed leukocyte reaction. The determinants on cultured lymphoblasts that stimulate autologous lymphocyte transformation were characterized with regard to their susceptibility to enzymatic destruction. A relationship of these determinants to the concanavalin A binding sites on lymphoblasts was demonstrated.

\section{METHODS}

Heparin used in these studies was obtained from Organon, Inc., West Orange, N. J. The tissue culture medium used in these studies was RPMI 1640 containing penicillin 100 $\mathrm{U} / \mathrm{ml}$ and streptomycin $50 \mu \mathrm{g} / \mathrm{ml}$. The medium and fetal calf serum was purchased from Associated Biomedic Systems, Inc., Buffalo, N. Y. Phytohemagglutinin MR-69 was purchased from the Wellcome Research Labs, Kent, England. Phytohemagglutinin-M was purchased from Difco Labs, Detroit, Mich. Twice-crystalized bovine pancreati: trypsin, soybean trypsin inhibitor, and crystalline chymotrypsin were purchased from Sigma Chemical Co., St. Louis, Mo. Vibrio cholera neuraminidase was obtained from Behring Diagnostics, Inc., Woodbury, $\mathrm{N}$. Y. Concanavalin $A$ was a product of Calbiochem, Los Angeles, Calif. Monovalent concanavalin A was prepared by the method of Burger (personal communication) : $10 \mathrm{mg}$ of concanavalin A were mixed with $1 \mathrm{mg}$ of crystalline trypsin or chymotrypsin in $1 \mathrm{ml}$ of $0.2 \mathrm{~m}$ phosphate buffer $\mathrm{pH} 7.0$ and incubated for $5 \mathrm{hr}$ at $37^{\circ} \mathrm{C}$. The enzymatic reaction was stopped by the addition of $1 \mathrm{mg}$ of soybean trypsin inhibitor. Plastic tissue culture flasks were obtained from Falcon Plastics, Oxnard, Calif., and the glass test tubes from Bellco Glass, Inc., Vineland, N. J. Tritiated thymidine (specific activity 6.7 $\mathrm{Ci} / \mathrm{mm})$, and toluene-liquiflor scintillant were purchased from the New England Nuclear Corp., Boston, Mass. NCS 
solubilizer was purchased from the Nuclear Chicago Co., Arlington Heights, Ill.

Continuous human lymphoblast cultures. Continuous cultures of human lymphoblasts were established using methods of Broder, Glade, and Hirschhorn (10). 30-50 ml of heparinized blood $(10 \mathrm{U} / \mathrm{ml})$ was sedimented in the syringe at $37^{\circ} \mathrm{C}$ for $2-3 \mathrm{hr}$. Tlie white cell-rich plasma was expresser and leukocytes collected by centrifugation (150 y for 30 $\min )$. The leukocytes were suspended at a concentration of 1-3 $\times 10^{6}$ cells $/ \mathrm{ml}$ in culture medium and $20 \%$ fetal bovine serum to which L-glutamine $2 \mu$ moles $/ \mathrm{ml}$ were added. $10 \mathrm{ml}$ of this preparation was placed into $25 \mathrm{ml}$ culture flasks with $0.25 \mu \mathrm{g}$ of phytohemagglutinin MR-69. The flasks were tightly capped and incuhated horizontally at $37^{\circ} \mathrm{C}$. Twice weekly $5 \mathrm{ml}$ of the culture medium was removed and fresh medium (without phytohemagglutinin) added. After 30-90 days cell lines were established as manifested by the media becoming acidic and by the presence of clusters of lymphoblasts. $5 \mathrm{ml}$ of media and lymphoblasts from established cultures could then be transferred to $125-\mathrm{ml}$ flasks. The lymphoblast concentration ranged from 1 to $5 \times 10^{8}$ \% $\mathrm{ml}$. Lymphoblasts were collected by centrifugation (150 g for $10 \mathrm{~min}$ ) and normally resuspended at a concentration of $2 \times 10^{8} / \mathrm{ml}$ in culture medium. Cell viability was measured by the exclusion of trypan blue as described by Boyse, Old, and Chouroulinkov (11).

Thymidine incorporation by human blood lymphocytes. Stimulation of thymidine incorporation into lymphocyte I)NA by phytohemagglutinin or by autologous or allogeneic lymphoid cells was measured. Peripheral blood leukocytes were obtained as described above. The concentration of lymphocytes in the white cell-rich plasma was adjusted to $2 \times 10^{8} / \mathrm{ml}$. Lymphocyte transformation stimulated by phytohemagglutinin was measured by mixing $0.4 \mathrm{ml}$ of the leukocyte preparation with $1.6 \mathrm{ml}$ culture medium containing $0.025 \mathrm{ml}$ of the stock phytohemagglutinin-M $(5 \mathrm{ml}$ of sterile water added to vial) solution in $13 \times 100 \mathrm{~mm}$ sterile glass tubes covered with plastic closures. Cultures were incubated $66 \mathrm{hr}$ at $37^{\circ} \mathrm{C}$ in a $5 \% \quad \mathrm{CO}_{2} / 95 \%$ air atmosphere. $2 \frac{1}{2} \mu \mathrm{Ci}$ of thymidine $-{ }^{3} \mathrm{H}$ in $0.025 \mathrm{ml}$ was added and the incubation continued for $6 \mathrm{hr}$. The culture tubes were then filled with 0.15 M sodium chloride and the cells were collected by centrifugation. The supernatant was discarded and a drop of human serum added to each tube as carrier protein. $5 \%$ trichloroacetic acid was added and the resulting precipitate collected by centrifugation and washed once with trichloroacetic acid. The precipitate was dissolved in $1 \mathrm{ml}$ of NCS solubilizer. $0.6 \mathrm{ml}$ of solubilizer was added to $10 \mathrm{ml}$ of toluene-liquiflor scintillant and counted in a Beckman liquid scintillation counter.

Lymphocyte thymidine incorporation stimulated by irradiated autologous or allogeneic lymphoid cells was measured as follows: stimulator cells were isolated by centrifugation and resuspended in culture medium at a concentration of $2 \times 10^{3}$ lymphoid cells $/ \mathrm{ml}$. Stimulating leukocytes were irradiated with 3000 rads while stimulating cultured lymphoblasts were irradiated with 4500 rads from a cesium 137 source (Gammator M, Radiation Machinery Corp., Parsippany, N. J.). Peripheral blood lymphocytes in autologous plasma at a concentration of $2 \times 10^{6} 1 \mathrm{ymphocytes} / \mathrm{ml}$ served as responder cells. Mixed leukocyte cultures consisted of $1.2 \mathrm{ml}$ of culture medium to which were added $0.4 \mathrm{ml}$ of responder cells and $0.4 \mathrm{ml}$ of stimulator cells. The cultures were incubated in sterile glass tubes at $37^{\circ} \mathrm{C}$ for $114 \mathrm{hr}$ in a $5 \% \mathrm{CO}_{2} / 95 \%$ air atmosphere hefore the addition of 2.5 $\mu \mathrm{Ci}$ of thymidine- ${ }^{3} \mathrm{H}$. The cultures were processed as de-
TABLE I

Effecl of Gamma Irradiation on Thymidine Incorporation by Cultured Lymphoblasts and Blood Lymphocytes Mixed with Autologous Cultured Lymphoblasts*

\begin{tabular}{cccc}
\hline $\begin{array}{c}\text { Responder } \\
\text { cell }\end{array}$ & $\begin{array}{c}\text { Stimulator } \\
\text { cellt }\end{array}$ & $\begin{array}{c}\text { Irradiation } \\
\text { dose }\end{array}$ & $\begin{array}{c}\text { Thymidine } \\
\text { incorporation }\end{array}$ \\
\hline Cultured & & rads & cpm $\times 10^{-3}$ \\
lymphoblasts & & 1500 & 136.5 \\
& & 3000 & 66.7 \\
& & 4500 & 21.1 \\
Autologous & Autologous & 0.9 \\
lymphocytes & leukocytes & & 0.8 \\
Autologous & Cultured & 0 & \\
lymphocytes & lymphoblasts & 1500 & 23.1 \\
& & 3000 & 0.6 \\
& & 4500 & 0.5 \\
Cultured & Autologous & 0 & 116.7 \\
lymphoblasts & leukocytes & 1500 & 52.4 \\
& & 3000 & 22.9 \\
& & 4500 & 1.1 \\
\hline
\end{tabular}

* 2-ml mixtures of cultured lymphoblasts alone or mixtures of cultured lymphoblasts and autologous lymphocytes were incubated as described in methods. Responder cells were irradiated with the dose indicated. Results expressed as average of duplicate cultures in counts per minute per culture thymidine- ${ }^{3} \mathrm{H}$ incorporated.

$\ddagger$ Lymphocytes and cultured lymphoblasts irradiated with 4500 rads.

scribed ahove. All cultures were set up in duplicate or triplicate.

\section{RESULTS}

Responsc of cultured lymphoblasts and lymphocytes mixed with cultured lymphoblasts to gamma irradiation. To establish a "one-way" mixed leukocyte reaction, one population of lymphoid cells was irradiated prior to mixed culture. Lymphoblasts grown in continuous culture have a rapid rate of division and incorporate a large amount of thymidine (Table I). It was necessary to irradiate such cells with 4500 rads to completely inhibit their spontaneous incorporation of thymidine. Irradiated cultured lymphoblasts markedly stimulated thymidine incorporation by autologous lymphocytes in mixed culture. Thymidine incorporation by lymphocytes in mixed culture was compared with the thymidine incorporated by responder lymphocytes mixed with irradiated autologous leukocytes. Blood lymphocytes and cultured lymphoblasts differ in their sensitivity to gamma irradiation when measured by thymidine incorporation in mixed culture. Thus, thymidine incorporation by blood lymphocytes when mixed with irradiated cultured lympho- 


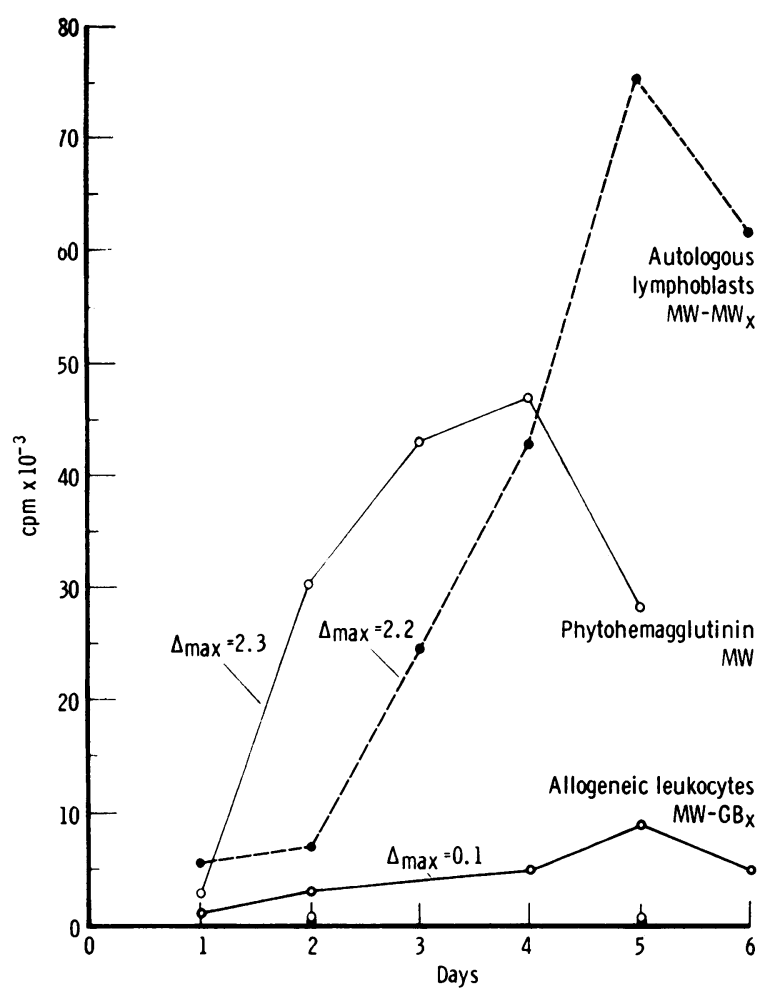

FigUre 1 Thymidine incorporation by lymphocytes mixed with autologous cultured lymphoblasts, allogeneic lymphocytes, or phytohemagglutinin during 6 days of incubation. Results are the average of three experiments performed and expressed as counts per min per culture thymidine ${ }^{3} \mathrm{H}$ incorporated. Lymphocytes from subject M. W. were mixed with phytohemagglutinin, with autologous irradiated lymphoblasts $\left(\mathrm{MW}-\mathrm{MW}_{\mathbf{x}}\right)$, or with irradiated allogeneic lymphocytes from subject $G$. B. $\left(M W-G B_{x}\right) . \Delta_{\max }$ indicates maximal slope in each of the three experimental conditions.

blasts was completely inhibited by 3000 rads while a dose of 4500 rads was necessary to completely inhibit thymidine incorporation by cultured lymphoblasts under identical circumstances. In each experiment described, mixture of irradiated lymphocytes with irradiated lymphoblasts showed that the proliferative capacity of each cell population had been completely inhibited by the irradiation dose employed.

Stimulation of thymidine incorporation into lymphocyte DNA by autologous cultured lymphoblasts and by phytohemagglutinin. The response of lymphocytes from six healthy volunteers to autologous cultured lymphoblasts, autologous blood leukocytes, and phytohemagglutinin was studied. Each of the six irradiated cultured lymphoblasts lines, established in culture for 1-6 months stimulated thymidine incorporation by autologous lymphocytes. Individual lymphoblastic lines were tested two to eight times and with rare and random exceptions were found to markedly stimulate autologous lymphocyte transformation. Results from two representative experiments are given in Table II. The maximal rate of thymidine incorporation stimulated by autologous lymphoblasts (measured at 5 days) is compared with that found when responder lymphocytes are mixed with phytohemagglutinin (measured at 3 days). The stimulation of thymidine incorporation into lymphocyte DNA by autologous cultured lymphohlasts is greater than that observed in the mixed (allogeneic) leukocyte reaction (Table III). During the course of our studies the amount of thymidine incorporated by lymphocytes in response to cultured autologous lymphoblasts ranged from 71 to $165 \%$ of the thymidine incorporated by the same lymphocyte preparation in the presence of phytohemagglutinin.

Kinetics of thymidine incorporation into lymphocyte DNA stimulated by phytohemagglutinin, autologous cultured lymphoblasts, and allogeneic leukocytes. Lymphocytes were cultured with autologous irradiated lymphoblasts, allogeneic leukocytes, or phytohemagglutinin for 24-128 $\mathrm{hr}$ before pulse labeling with tritiated thymidine (Fig. 1). Maximal thymidine incorporation by blood lymphocytes stimulated by phytohemagglutinin occurs after 72-96 hr in culture. Maximal thymidine incorporation into lymphocyte DNA stimulated by either allogeneic leukocytes or cultured lymphoblasts is found after 104

TABLE II

Stimulation of Lymphocyte Thymidine Incorporation $b^{\prime}$ Autologous Cultured Lymphoblasts, Autologous Leukocytes, or Phytohemagglutinin*

\begin{tabular}{|c|c|c|c|}
\hline \multirow[b]{2}{*}{$\begin{array}{l}\text { Responder } \\
\text { cell } \\
\text { donor }\end{array}$} & \multicolumn{3}{|c|}{ Thymidine incorporation stimulated by: } \\
\hline & $\begin{array}{l}\text { Autologous } \\
\text { blood } \\
\text { leukocytes }\end{array}$ & $\begin{array}{l}\text { Autologous } \\
\text { lymphoblasts }\end{array}$ & $\begin{array}{c}\text { Phyto- } \\
\text { hemagglutinin }\end{array}$ \\
\hline & & $c p m \times 10^{-3}$ & \\
\hline L. B. & 0.6 & 101.3 & 88.3 \\
\hline L. B. & 0.9 & 63.7 & 81.6 \\
\hline C. B. & 0.6 & 54.7 & 62.2 \\
\hline C. B. & 0.4 & 32.9 & 46.2 \\
\hline H. G. & 0.8 & 156.2 & 186.4 \\
\hline H. G. & 0.7 & 96.3 & 88.3 \\
\hline R. R. & 0.3 & 74.4 & 76.8 \\
\hline R. R. & 0.4 & 89.3 & 98.2 \\
\hline J. U. & 0.9 & 82.3 & - \\
\hline J. U. & 0.9 & 109.8 & 96.2 \\
\hline M. W. & 0.4 & 141.3 & 101.6 \\
\hline M. W. & 0.8 & 96.7 & 63.9 \\
\hline
\end{tabular}

* Leukocytes from each subject were mixed with autologous leukocytes, autologous cultured lymphoblasts, or phytohemagglutinin. Results from two representative experiments with each cell donor shown. 
hr. The increase in the rate of thymidine incorporation during the incubation of lymphocytes with autologous lymphoblasts parallels that seen with phytohemagglutinin and differs from that seen in a one-way mixed leukocyte reaction. Whether this difference in stimulating capacity of allogeneic leukocytes and autologous lymphoblasts is due to the activation of different populations of lymphocytes or to stimulation of a different rate of cell division is not clear.

Lymphocyte stimulation by allogeneic leukocytes and cultured lymphoblasts. Lymphocyte transformation stimulated by optimal concentrations (9) of cultured lymphoblasts and of allogeneic leukocytes was compared. The results of four representative experiments are shown in Table III. The stimulation of lymphocyte transformation is measured relative to the "background" amount of thymidine incorporated by lymphocytes mixed with irradiated autologous leukocytes. Allogeneic leukocytes stimulate a 10-93-fold increase in thymidine incorporated into lymphocyte DNA. Allogeneic lymphoblasts stimulated a 40-270-fold increase in thymidine incorporation. Allogeneic cultured lymphoblasts always stimulated more thymidine incorporation than did allogeneic leukocytes. No relationship was observed between the degree of stimulation of thymidine incorporation by allogeneic leukocytes and by cultured lymphoblasts from the same donor. Thus, the cell donor whose leukocytes most stimulated lymphocyte transformation was not necessarily the donor

TABLE III

Stimulation of Lymphocyte Thymidine Incorporation hy. Autologous and Allogeneic Leukocytes and Cultured Lymphoblasts*

\begin{tabular}{|c|c|c|c|c|c|}
\hline \multirow{3}{*}{$\begin{array}{l}\text { Responder } \\
\text { cell } \\
\text { donor }\end{array}$} & \multirow{3}{*}{$\begin{array}{c}\text { Stimulator } \\
\text { cell } \\
\text { donor }\end{array}$} & \multicolumn{4}{|c|}{ Thymidine incorporation stimulated by: } \\
\hline & & \multicolumn{2}{|c|}{ Leukocytes } & \multicolumn{2}{|c|}{$\begin{array}{c}\text { Cultured } \\
\text { lymphoblasts }\end{array}$} \\
\hline & & $\begin{array}{l}\text { Autol- } \\
\text { ogous }\end{array}$ & $\begin{array}{c}\text { Allo- } \\
\text { geneic }\end{array}$ & $\begin{array}{c}\text { Autol- } \\
\text { ogous }\end{array}$ & $\begin{array}{l}\text { Allo- } \\
\text { geneic }\end{array}$ \\
\hline & & $c p m$ & $10^{-3}$ & $c p m$ & $\times 10^{-3}$ \\
\hline G. B. & - & 1.5 & - & 1.32 .1 & - \\
\hline G. B. & M. W. & $\cdots$ & 77.0 & 一 & 187.9 \\
\hline L. B. & - & 0.6 & -- & 45.6 & - \\
\hline L. B. & M. W. & $-\cdots-$ & 6.2 & & 29.9 \\
\hline L. B. & G. B. & $\cdots$ & 14.5 & - & 29.0 \\
\hline L. B. & J. U. & 一 & 12.4 & -- & 41.7 \\
\hline J. U. & - & 0.6 & - & 41.2 & \\
\hline J. U. & M. W. & $\cdots$ & 8.6 & --- & 39.5 \\
\hline J. U. & G. B. & -- & 16.4 & - & 24.3 \\
\hline J. U. & I. B. & $\cdots$ & 11.9 & - & 60.2 \\
\hline M. W. & - & 0.6 & & 1.39 .5 & $-\cdots \cdot$ \\
\hline M. W. & G. B. & - & 16.3 & -- & 105.3 \\
\hline M. W. & J. U. & - & 56.1 & $\cdots$ & 166.6 \\
\hline
\end{tabular}

* Mixed leukocyte culture was established as described in methods. Results expressed as average of triplicate cultures in counts per minute per culture thymidine- ${ }^{3} \mathrm{H}$ incorporated.
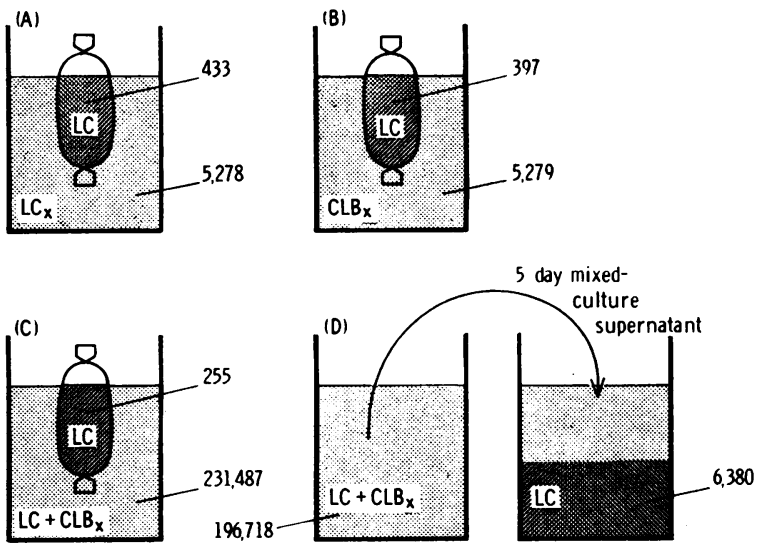

Figure 2 Lymphocyte transformation by cells separated from cultured lymphoblasts. 10 -ml cultures containing $8 \times$ $10^{6}$ irradiated lymphocytes ( $\left.\mathrm{LC}_{\mathbf{x}}\right), 8 \times 10^{6}$ irradiated cultured lymphoblasts $\left(\right.$ CLB $\left._{x}\right)$, or a mixture of $4 \times 10^{8}$ irradiated cultured lymphoblasts and $4 \times 10^{8}$ autologous lymphocytes (LC) were incubated 5 days at $37^{\circ} \mathrm{C}$ on a rotary shaker. In experiments $\mathrm{A}, \mathrm{B}$, and $\mathrm{C}$ a dialysis sac containing $4 \times 10^{5}$ lymphocytes in $1 \mathrm{ml}$ of complete medium was suspended in the $10-\mathrm{ml}$ cultures. The Visking dialysis tubing was boiled in $0.001 \mathrm{M}$ EDTA $\mathrm{pH} 7.2$ and washed with medium before the addition of the cells. At the end of 5 days dialysis bags were opened and contained cells were placed in culture tubes. Tritiated thymidine was added to all cultures at a concentration of $1 \mu \mathrm{Ci} / \mathrm{ml} .4 \mathrm{hr}$ later, the trichloroacetic acid precipitable radioactivity was measured. In experiment $\mathrm{D}, 5 \mathrm{ml}$ of supernatant from a 5 day mixed culture was added to $5 \mathrm{ml}$ of fresh medium containing $8 \times$ $10^{6}$ lymphocytes and cultured 5 days. The results expressed are the average of three independent experiments given as counts per minute in each culture vessel.

of the lymphoblast culture which was the most potent stimulator of lymphocyte transformation. Autologous cultured lymphoblasts stimulated more lymphocyte transformation than did allogeneic lymphoblasts in six out of nine comparisons. There is, however, no statistically significant difference in the stimulatory capacity of allogeneic and autologous culture lymphoblasts.

Importance of physical contact between stimulator and responder cells in mixed cell culture. Lymphocytes suspended within a dialysis sac in a culture vessel containing either autologous cultured lymphoblasts or a mixture of cultured lymphoblasts and autologous leukocytes are not stimulated to transform. Results from the three experiments performed are shown in Fig. 2. Lymphocytes separated by a semipermeable membrane from lymphoblasts or a mixture of lymphoblasts and leukocytes incorporated no more thymidine than they do in the presence of autologous leukocytes. Thus, lymphocyte transformation does not occur without physical contact with lymphoblasts. Several investigators $(12,13)$ have found that lymphocyte transformation does not occur in the mixed leukocyte reaction if the two lymphocyte population are separated by a semipermeable membrane. 
TABLE IV

Thymidine Incorporation by Lymphocytes Stimulated b.y Inlact and Disrupted Autologous Lymphoblasts*

\begin{tabular}{lcr}
\hline & \multicolumn{2}{c}{$\begin{array}{c}\text { Thymidine } \\
\text { incorporated }\end{array}$} \\
\cline { 2 - 3 } & Exp. 1 $\quad$ Exp. 2 \\
\hline & \multicolumn{2}{c}{$c p m \times 10^{-3}$} \\
Intact autologous leukocytes & 0.4 & 0.6 \\
Intact autologous lymphoblasts & $1+1.3$ & 101.3 \\
I)isrupted autologous lymphoblasts & & \\
Unfractionated & 12.1 & 8.6 \\
Supernate fraction & 5.1 & 4.1 \\
Precipitate fraction & 5.8 & 3.1
\end{tabular}

* 2-ml mixtures of cultured lymphoblasts and autologous lymphocytes were incubated under conditions described in methods.

$\$ 8 \times 10^{5}$ washed, irradiated, cultured lymphoblasts per $\mathrm{ml}$ medium RPMI 1640 were frozen (dry ice and acetone) and thawed four times. A portion of the disrupted lymphoblast preparation was centrifuged at $800 \mathrm{~g}$ for $15 \mathrm{~min}$. The precipitate was resuspended in the original volume of medium RPMI 1640. $1 \mathrm{ml}$ of the disrupted lymphoblast preparation or of the supernatant or of the precipitate was mixed with 1 $\mathrm{ml}$ of RPMI 1640 containing $8 \times 10^{5}$ autologous leukocytes and $40 \%$ autologous plasma. The final plasma concentration was $20 \%$ in all experiments.

No mitogenic factor capable of passing through a semipermeable membrane ( $\mathrm{mol}$ w.t less than 10,000 ) was demonstrated. The presence of diffusible mitogens too large to pass through a dialysis membrane was tested by adding supernatant medium from 5-day mixed cell cultures to fresh leukocytes. These supernatants were not iound to stimulate lymphocyte transformation. It remains possible that mitogenic factors are produced which are effective only over very short distances.

Stimulation of thymidine incorporation into lymphocyte INA by intact and disrupted cultured lymphoblasts. The capacity of disrupted cultured lymphoblasts to stimulate autologous lymphocyte transformation was tested. The results of two experiments representative of the five performed are shown in Table IV. Lymphoblasts were disrupted by repeated freezing and thawing. Microscopic inspection of the preparation showed that no intact cells remained after this treatment. More than $90 \%$ of the stimulation of thymidine incorporation into lymphocyte DNA by autologous cultured lymphoblasts was lost following this treatment. The disrupted lymphoblasts were centrifuged at $800 \mathrm{~g}$ for $15 \mathrm{~min}$. The supernatant fractions and resuspended precipitant fraction were mixed with autologous leukocytes. Less than $10 \%$ of the stimulatory activity of intact lymphoblasts was demonstrated in either supernatant or precipitant fractions of the disrupted lymphoblasts. These results demon- strate the importance of the physical integrity of lymphoblasts to the stimulation of lymphocyte transformation but do not distinguish between disruption of a cellsurface site or the capacity of intact cells to synthesize a stimulator.

Effect of trypsin and neuraminidase on the stimulatory dcterminants on culturcd lymphoblasts. The effect of trypsin and neuraminidase on the stimulatory determinants of cultured lymphoblasts was investigated. Incubation of lymphoblasts with $100 \mu \mathrm{g} / \mathrm{ml}$ of trypsin for 30 min at $37^{\circ} \mathrm{C}$ reduced their capacity to stimulate thymidine incorporation by autologous lymphocytes by $90 \%$ ( Table V). Incubation of leukocytes with trypsin did not endow them with a capacity to stimulate autologous lymphocyte transformation. The effect of trypsin on the lymphoblast stimulatory determinants could be inhibited by soybean trypsin inhibitor suggesting that the activity of the trypsin preparation was due to its proteolytic activity. Incubation of cultured lymphoblasts with 1-100) $\mathrm{U} / \mathrm{ml}$ of Vibrio cholera neuraminidase has no effect on their capacity to stimulate lymphocyte transformation. The concentration $(50 \mathrm{U} / \mathrm{ml})$ of neuraminidase chosen for repeated study (Table VI) was that found in unpublished studies to maximally alter the in vivo migration of syngeneic lymphocytes. Neither enzyme reduced the viability of the lymphoblasts as measured by trypan blue dye exclusion. Although the trypsin-treated cul-

\section{TABLE V}

Effert of Trypsin-Treatment of Cultured Lymphoblasts on their Stimulation of A utologous Lymphoryte Transformation*

\begin{tabular}{|c|c|c|}
\hline \multirow{3}{*}{ Stimulator cell } & \multicolumn{2}{|c|}{$\begin{array}{l}\text { Thymidine } \\
\text { incorporated }\end{array}$} \\
\hline & Exp. 1 & lixp. \\
\hline & \multicolumn{2}{|c|}{$c p m \times 10^{-3}$} \\
\hline Autologous leukocytes & 0.8 & 0.5 \\
\hline $\begin{array}{l}\text { Autologous leukocytes incubated with } \\
\text { trypsin }(100 \mu \mathrm{g} / \mathrm{ml})\end{array}$ & 0.9 & 0.5 \\
\hline $\begin{array}{l}\text { Autologous lymphoblasts } \\
\text { (no trypsin incubation) }\end{array}$ & 113.6 & 52.3 \\
\hline $\begin{array}{l}\text { Autologous lymphoblasts incubated } \\
\text { with trypsin }\end{array}$ & & \\
\hline $100 \mu \mathrm{g} / \mathrm{ml}$ & 10.3 & 3.5 \\
\hline $200 \mu \mathrm{g} / \mathrm{ml}$ & +.3 & 3.1 \\
\hline $500 \mu \mathrm{g} / \mathrm{ml}$ & 0.3 & 0.5 \\
\hline
\end{tabular}

* Washed cultured lymphoblasts or washed leukocytes were incubated with varying concentrations of trypsin for $30 \mathrm{~min}$ at $37^{\circ}$ prior to irradiation. The cells were then washed three times with RPMI 1640 and resuspended in RPMI 1640 with $20 \%$ autologous plasma at a concentration of $8 \times 10^{5}$ cells. $1 \mathrm{ml}$ irradiated cells was mixed with autologous leukocytes. Results are expressed as mean of duplicate cultures in counts per minute per culture thymidine- ${ }^{3} \mathrm{H}$ incorporated. 
TABLE VI

Effect of Incubating Cultured Lymphoblasts with Neuraminidase or Trypsin on their Stimulation of Autologous Lymphocytes Transformation*

\begin{tabular}{|c|c|c|}
\hline \multirow{2}{*}{ Stimulator cell } & \multicolumn{2}{|c|}{$\begin{array}{l}\text { Thymidine } \\
\text { incorporation }\end{array}$} \\
\hline & Exp. 1 & Exp. 2 \\
\hline & \multicolumn{2}{|c|}{$c p m \times 10^{-3}$} \\
\hline Autologous leukocytes & 0.6 & 0.3 \\
\hline Autologous lymphoblasts & 132.7 & 69.4 \\
\hline Neuraminidase-treated autologous & & \\
\hline lymphoblasts & 128.5 & 72.6 \\
\hline $\begin{array}{l}\text { Trypsin-treated autologous } \\
\text { lymphoblasts }\end{array}$ & 29.1 & 10.4 \\
\hline $\begin{array}{l}\text { Autologous lymphoblasts incubated } \\
\text { with trypsin in presence of Soybean } \\
\text { trypsin inhibitor }\end{array}$ & 125.9 & 79.2 \\
\hline $\begin{array}{l}\text { Mixture of trypsin-treated and } \\
\text { untreated autologous lymphoblasts }\end{array}$ & 147.3 & 65.8 \\
\hline
\end{tabular}

* 2-ml mixtures or irradiated cultured lymphoblasts or irradiated lymphoblasts with autologous lymphocytes were incubated under conditions described in methods. Where indicated, washed cultured lymphoblasts were incubated for $30 \mathrm{~min}$ at $37^{\circ} \mathrm{C}$ with $50 \mathrm{U} / \mathrm{ml}$ neuraminidase, $100 \mu \mathrm{g} / \mathrm{ml}$ trypsin, or $100 \mu \mathrm{g} / \mathrm{ml}$ trypsin and $100 \mu \mathrm{g} / \mathrm{ml}$ soybean trypsin inhibitor. The cells were then washed three times with RPMI 1640 and resuspended in RPMI 1640 with $20 \%$ autologous plasma at a concentration of $8 \times 10^{5}$ cells $/ \mathrm{ml}$, irradiated and mixed with autologous lymphocytes. In the last group, $1 \mathrm{ml}$ of responder cells was mixed with $\frac{1}{2} \mathrm{ml}$ of trypsin-treated and $\frac{1}{2} \mathrm{ml}$ of untreated cultured lymphoblasts. Results expressed as mean of triplicate cultures in counts per minute per culture thymidine $-{ }^{3} \mathrm{H}$ incorporated.

tured lymphoblasts were washed, the possible effect of incompletely removed trypsin upon the responding cells was tested. Lymphocytes were stimulated with a combination of enzyme-treated and untreated lymphoblasts. Table VI shows that the trypsin-treated lymphoblasts did not impair the stimulation of lymphocyte transformation by untreated lymphoblasts.

The capacity of trypsin-treated cultured lymphoblasts to regenerate their stimulatory determinants was next studied. Cultured lymphoblasts were treated with trypsin and returned to culture for various times before their irradiation and mixture with autologous lymphocytes. Cultured lymphoblasts treated with trypsin immediately prior to mixed culture stimulate little transformation of autologous lymphocytes. Trypsin-treated cultured lymphoblasts recover their capacity to stimulate lymphocytes transformation when returned to culture for $24 \mathrm{hr}$. Complete regeneration of the stimulatory deterninants occurred in 30-48 hr (Table VII). As the viability of cultured lymphoblasts is not depressed after incubation with trypsin, the regeneration of stimulatory activity by cul- tured lymphoblasts cannot be explained solely by the multiplication of cells unaffected by trypsin treatment.

Detection of concanavalin $A$ binding sites on cultured lymphoblasts. A variety of neoplastic cells have concanavalin A binding sites not found on normal cells (14). Concanavalin $\mathrm{A}$ at concentrations between 100 and 500 $\mu \mathrm{g} / \mathrm{ml}$ was found to agglutinate cultured lymphoblasts (Table VIII). Significant agglutination was found with each of three cultured lymphoblast lines studied. Purified blood lymphocytes (15) from the lymphoblast donors showed only trace agglutination at the highest concentration of concanavalin A tested.

The relationship between the concanavalin A binding sites on the cultured lymphoblast and their stimulation of autologous lymphocyte transformation was studied. As concanavalin $\mathrm{A}$ is a potent mitogen it could not itself be used for such studies. Trypsin-treated concanavalin A has been shown by Burger and Noonan to retain its capacity to bind but not to agglutinate transformed cells (16). We found that trypsin-treated concanavalin A retained little mitogenic activity (Table IX) and did not depress the viability of cultured lymphoblasts as measured by a trypan blue assay. A mixture of concanavalin $\mathrm{A}$ and trypsin-treated concanavalin A stimulated lymphocyte transformation normally. This proved the absence of an inhibitor of lymphocyte transformation in the trypsin-treated concanavalin preparation. The effect of trypsin-treated concanavalin A on the stimulatory capacity of cultured lymphoblasts was investigated. Cultured lymphoblasts incubated for $30 \mathrm{~min}$ with trypsintreated concanavalin A stimulated significantly less lymphocyte transformation than did untreated cultured lym-

\section{TABLE VII}

Recovery of Trypsin-treated Cultured Lymphoblast (CLB) Stimulatory Capacity*

\begin{tabular}{|c|c|c|c|}
\hline \multirow[b]{2}{*}{ Stimulator cell } & \multirow{2}{*}{$\begin{array}{l}\text { Interval between } \\
\text { trypsinf-treatment } \\
\text { and culture }\end{array}$} & \multicolumn{2}{|c|}{$\begin{array}{l}\text { Thymidine } \\
\text { incorporated }\end{array}$} \\
\hline & & Exp. 1 & Exp. 2 \\
\hline & $h r$ & $c p m$ & $\times 10^{-3}$ \\
\hline Autologous leukocytes & Not treated & 0.7 & 0.4 \\
\hline Autologous CLB & Not treated & 68.4 & 96.1 \\
\hline Autologous CLB & 1 & 2.8 & 3.2 \\
\hline Autologous CLB & 6 & - & 5.7 \\
\hline Autologous CLB & 24 & 2.3 .7 & 35.7 \\
\hline Autologous CLB & 30 & - & 89.4 \\
\hline Autologous CLB & 48 & 59.4 & 102.4 \\
\hline
\end{tabular}

* 2-ml cultures of irradiated CLB mixed with autologous lymphocyte: were incubated under conditions described in methods. Results expressed as mean count per culture per triplicated cultures.

† Lymphoblasts were washed with medium RPMI 1640 and resuspended in medium containing trypsin $200 \mu \mathrm{g} / \mathrm{ml}$ for $30 \mathrm{~min}$ at $37^{\circ} \mathrm{C}$. The lymphoblasts were then separated from trypsin by centrifugation, washed three times and resuspended in RPMI 1640 containing $20 \%$ fetal calf serum. The lymphoblasts were cultured for various times prior to irradiation and mixture with autologous lymphocytes. 
TABLE VIII

Aglutination of Blood Lymphocytes and Cultured Lymphoblasts by Concanavalin $A^{*}$

\begin{tabular}{|c|c|c|c|c|c|}
\hline \multirow{3}{*}{$\begin{array}{l}\text { Concanavalin A } \\
\text { concentration }\end{array}$} & \multicolumn{5}{|c|}{ Agglutination } \\
\hline & \multicolumn{3}{|c|}{ Cultured lymphoblasts } & \multicolumn{2}{|c|}{ Lymphocytes } \\
\hline & G. B. & R. R. & M. W. & G. B. R. R. & M. W. \\
\hline \multicolumn{6}{|l|}{$\mu g / m l$} \\
\hline 50 & ++ & + & . & & $\ldots$ \\
\hline 100 & ++ & + & + & & $\ldots$ \\
\hline 250 & +++ & ++ & +++ & --- & -- \\
\hline 500 & ++++ & $++t+$ & $+t+t$ & + & ++ \\
\hline
\end{tabular}

* Lymphocytes were purified from blood as described by Mendelsohn, Skinner, and Kornfeld (15). Washed cultured lymphoblasts and purified lymphocytes at a concentration of $2.5 \times 10^{6} \mathrm{cells} / \mathrm{ml}$ were suspended in RPMI 1640 containing $50-500 \mu \mathrm{g} / \mathrm{ml}$ concanavalin $\mathrm{A}$. The agglutination of cells was determined by microscopic examination and scored 1 to $4+$ after incubation at $37^{\circ} \mathrm{C}$ for 30 minutes.

phoblasts. These findings suggest that the sites on the cultured lymphoblasts that stimulate lymphocyte transformation and that bind concanavalin A may be in close proximity to one another.

\section{DISCUSSION}

These studies demonstrate that cultured lymphoblasts markedly stimulate lymphocyte transformation in mixed culture. Cultured lymphoblasts are 2 to 10 times more potent stimuli of lymphocyte transformation than are allogeneic leukocytes. The stimulation of lymphocyte transformation by cultured lymphoblasts resembles the mixed leukocyte reaction in several respects: $(a)$ the

\section{TABLE IX}

Effect of Trypsin-Treated Concanavalin A on the Stimulatory Determinants of Cultured Lymphoblasts

\begin{tabular}{lcc}
\hline \multirow{2}{*}{$\begin{array}{c}\text { Stimulus of lymphocyte } \\
\text { transformation* }\end{array}$} & \multicolumn{2}{c}{ Thymidine incorporated } \\
\cline { 2 - 3 } & Exp. 1 & Exp. 2 \\
\hline & \multicolumn{2}{c}{$c p m \times 10^{-3}$} \\
Concanavalin A & 42.3 & 12.4 \\
Trypsin-treated concanavalin & 5.4 & 2.6 \\
Concanavalin A and trypsin- & & \\
treated concanavalin A & 55.2 & 11.9 \\
Autologous leukocytes & 0.4 & 0.4 \\
$\begin{array}{l}\text { Autologous lymphoblasts } \\
\text { Autologous lymphoblasts incu- }\end{array}$ & 54.6 & 19.8 \\
$\quad$ bated with trypsin-treated & & \\
concanavalin A & 8.1 & 6.7 \\
\hline
\end{tabular}

* Responder cells were established in $2 \mathrm{ml}$ culture as described in methods. $80 \mu \mathrm{g}$ of concanavalin A and/or $80 \mu \mathrm{g}$ trypsin-treated concanavalin A were added to cultures as indicated. Cultured lymphoblasts were incubated with trypsin-treated concanavalin $\mathrm{A}$ for $30 \mathrm{~min}$ at $37^{\circ} \mathrm{C}$ and washed twice prior to their mixture with autologous leukocytes. time required for maximal lymphocyte transformation, (b) the necessity for intact cultured lymphoblasts in physical contact with the responding cell population (4, 17 ), and (c) the lack of participation of widely diffusible mitogenic factors.

Amos and Bach (18) have shown that the mixed leukocyte reaction is dependent upon differences in determinants identical or closely linked to the histocompatibility antigens. In contrast, lymphocyte transformation stimulated by cultured lymphoblasts is not related to differences in the HL-A determinants on the lymphoblast as evidenced by the observations that: (a) lymphoblasts stimulate autologous lymphocyte transformation, (b) the response of lymphocytes to allogeneic cultured lymphoblasts does not parallel their response to allogeneic leukocytes from the cell line donor. and $(c)$ the kinetics of thymidine incorporation stimulated by autologous lymphoblasts resembles the response to phytohemagglutinin more than it does a mixed leukocyte reaction. There is evidence that HL-A antigenic density is greater on cultured lymphoblasts than on peripheral lymphocytes (19). This observation may contribute to the increased response of lymphocytes to allogeneic cultured lymphoblasts as compared with allogeneic leukocytes from the cell line donor and may underlie the reported appearance of "new" HL-A determinants on cultured lymphoblasts ( 8 . 20 ).

The results reported here suggest that presence of a lymphoblast-associated antigen. The existence of determinants on lymphoblasts not found on lymphocytes has been suggested by cross-absorption studies using antiserum raised to lymphoblasts and to blood lymphocytes (21). Recent studies by Mann, Rogentine, Halterman, and Leventhal (22) showed that a non-HL-A determinant found on cultured lymphoblasts is present on leukocytes from leukemic patients and some of their relatives but not on the leukocytes of unrelated normal individuals. This is relevant because leukemic cells have been reported to stimulate transformation of autologous lymphocytes (23) and of lymphocytes from HL-A identical siblings (24). These findings suggested the existence of a leukemia-associated antigen. It is possible that the lymphoblast-associated antigen may be related to a leukemiaassociated antigen.

Tumor cells, cells transformed by viral and chemical carcinogens (14), and embryonic cells (25) possess phytagglutinin binding sites not found on normal cells. We have studied the binding of one such phytagglutinin. concanavalin A. Concanavalin A binding sites were shown to be present on cultured lymphoblasts but not on lymphocytes. Cultured lymphoblasts that have bound trypsin-treated concanavalin A (nonmitogenic) do not stimulate autologous lymphocyte transformation suggesting that concanavalin $\mathrm{A}$ binding sites are in close 
proximity to the determinants that stimulate lymphocyte transformation. The two sites are probably distinct since they differ in their response to trypsin. Concanavalin A binding sites are unaffected by incubation with trypsin. In fact, treatment of normal cells with trypsin exposes cryptic concanavalin A binding sites (26). In contrast, treatment of cultured lymphoblasts with trypsin destroys the sites that stimulate autologous lymphocyte transformation.

The biologic mechanism underlying the appearance on tumor cells and transformed cells of phytagglutinin binding sites and of new antigenic determinants is not known. Two hypotheses proposed to explain the development of such surface sites are germane to this discussion. One hypothesis suggests that new antigenic sites result from the derepression of host genetic material normally expressed only during early periods of growth and development (27). The best studied example of this phenomenon is the demonstration by Gold and Freedman (28) of an antigenic determinant on colonic carcinoma cells which is also present on embryonic endodermal tissue. The second hypothesis proposes that cells with new antigenic determinants are infected with virus and that the new determinant results from the expression of viral genetic material. Many surface determinants results from the expression of viral genetic material (29).

At present, there is no evidence that new antigenic determinants found on the cultured lymphoblast are present on primitive hematopoietic cells. We have, however, preliminary evidence that mitogen-induced lymphoblasts also stimulate autologous lymphocyte transformation and may contain similar antigenic determinants (30).

Cultured lymphoblasts are frequently infected with EB virus. In fact, it has been suggested that in vivo (31) or in vitro (32) infection with the EB virus is a prerequisite for the establishment of lymphoblasts in continuous culture. EB virus or EB antigen can be demonstrated in the majority of cultured lymphoblast lines (31). Cultured lymphoblast lines that possess neither EB virus nor $\mathrm{EB}$ antigen can be shown to contain the $\mathrm{EB}$ viral genome by DNA-RNA hybridization techniques (33) and recently EB virus has been induced from presumed "virus-free" lines after incubation with bromodeoxyuridine $(34,35)$. At this time it is not possible to rule out a relationship between $\mathrm{EB}$ virus infection and the development of the stimulatory determinants on cultured lymphoblasts. Although cultured lymphoblasts that stimulate autologous lymphocyte transformation do not always have demonstrable EB viral antigens (9), it is possible that $\mathrm{EB}$ viral antigens contribute to the stimulation of lymphocyte transformation. Whether EB viral antigens are destroyed following exposure to trypsin is not known.
Finally, the biological significance of the in vitro response of lymphocytes to autologous cells should be considered. The transformation of lymphocytes in culture may reflect the in vitro phenomenon of immune surveillance. The disappearance of atypical lymphocytes from the circulation during recovery from infectious mononucleosis follows and may result from the sensitization of the host to determinants on the atypical lymphocyte. This may be the biologic consequence of the in vitro phenomenon described in these studies. In general terms the ability of lymphocytes from normal individuals to react with blast transformation to cultured autologous cells may reflect a primary mechanism to control neoplastic transformation.

\section{ACKNOWLEDGMENTS}

This work was supported in part by The American Cancer Society Clinical Investigation Grant 28 and the U. S. Public Health Service Training Grant AI-00255.

\section{REFERENCES}

1. Moore, G. E., J. T. Grace, Jr., P. Citron, R. Gerner, and A. Burns. 1966. Leukocyte cultures of patients with leukemia and lymphomas. N. Y. State J. Med. 66: 2757.

2. Pope, J. H. 1967. Establishment of cell lines from peripheral leukocytes in infectious mononucleosis. $\mathrm{Na}$ ture (Lond.). 216: 810 .

3. Moore, G. E., R. E. Gerner, and H. A. Franklin. 1967. Culture of normal human leukocytes. J. Am. Med. Assoc. 199: 519 .

4. Hardy, D. A., S. Knight, and N. R. Ling. 1970. The interaction of normal lymphocytes and cells from lym. phoid cell lines. I. The nature of the activation process. Immunology. 19: 329.

5. Green, S. S., and K. W. Sell. 1970. Mixed leukocyte stimulation of normal peripheral leukocytes by autologous lymphoblastoid cells. Science (Wash. D. C.). 170: 989.

6. Knight, S. C., G. E. Moore, and B. D. Clarkson. 1971 Stimulation of autchthonous lymphocytes by cells from normal and leukaemic lines. Nat. New Biol. 229: 185.

7. Flier, J. S., P. R. Glade, S. W. Broder, and K. Hirschhorn. 1970. Lymphocyte stimulation by allogeneic and autochthonous cultured lymphoid cells. Cellular Immunology. 1: 596.

8. Han, T., G. E. Moore, and J. E. Sokal. 1971. In vitro lymphocyte response to autologous cultured lymphoid cells. Proc. Soc. Exp. Biol. Med. 136: 976.

9. Birnbaum, G., G. W. Siskind, and M. E. Weksler. 1972. Autologous and allogeneic stimulation of peripheral human leukocytes. Cellular Immunology. 3: 44.

10. Broder, S. W., P. R. Glade, and K. Hirschhorn. 1970. Establishment of long-term lines from small aliquots of normal lymphocytes. Blood. 35: 539 .

11. Boyse, E. A. L. J. Old, and I. Chouroulinkov. 1964. Cytotoxic test for demonstration of mouse antibody. Methods Med. Res. 10: 39.

12. Chapman, N. D., and R. W. Dutton. 1965. The stimulation of DNA synthesis in cultures of rabbit lymph node and spleen cell suspensions by homologous cells. J. Exp. Med. $121: 85$. 
13. Moorhead, J. F., J. J. Connolly, and W. McFarland. 1967. Factors affecting the reactivity of human lymphocytes in vitro. I. Cell number, duration of culture, and surface area. J. Immunol. 99: 413.

14. Inbar, M., and L. Sachs. 1969. Interaction of the carbohydrate-binding protein concanavalin $\mathrm{A}$ with normal and transformed cells. Proc. Natl. Acad. Sci. U. S. A. $63: 1418$.

15. Mendelsohn, J., A. Skinner, and S. Kornfeld. 1971. The rapid induction by phytohemmagglutinin of increased $\alpha$-aminoisobutyric acid uptake by lymphocytes. J. Clin. Invest. 50: 818 .

16. Burger, M. M., and K. D. Noonan. 1970. Restoration of normal growth by covering of agglutinin sites on tumor cell surface. Nature (Lond.). 228: 512.

17. Schellekens, P. Th. A., and V. P. Eijsvoogel. 1970 Lymphocyte transformation in vitro. III. Mechanism of stimulation in the mixed lymphocyte culture. Clin. Exp. Immunol, $7: 229$.

18. Amos, D. B., and F. A. Bach. 1968. Phenotypic expressions of the major histocompatibility locus in man (HL-A): leukocyte antigens and mixed leukocyte culture reactivity. $J$. Exp. Med. 128: 623 .

19. Kourilsky, F. M., D. Silvestre, J. P. Levy, J. Dausset, M. G. Nicolai, and A. Senik. 1971. Immunoferritin study of the distribution of HL-A antigens on human blood cells. J. Immunol. 106: 454

20. Moore, G. E., and L. Woods. 1972. Isoantigens of cultured human lymphoid cells. Transplantation. 13: 155.

21. Perper, R. J., T. Z. Yu, and J. B. Kooistra. 1970. The in vitro specificity of antilymphocyte sera produced by either cultured or noncultured lymphocytes. Int. Arch. Allergy' Appl. Immunol. $37: 418$.

22. Mann, D. L., G. N. Rogentine, R. Halterman, and B. Leventhal. 1971. Detection of an antigen associated wit! acute leukemia. Science (Wash. D. C.). 174: 1136.

23. Fridman, W. H., and F. M. Kourilsky. 1969. Stimulation of lymphocytes by autologous leukaemic cells in acutc leukaemia. Nature (Lond.). $224: 277$.

24. Bach. M. L., F. H. Bach, and P. Joo. 1969. Leukemia- associated antigens in mixed leukocyte culture test. Science (Wash. D. C.). 166: 1520.

25. Moscona, A. A. 1971. Embryonic and neoplastic cell surfaces: availability of receptors for concanavalin A and wheat germ agglutinin. Science (Wash. D. C.). $171: 905$.

26. Burger, M. M. 1969. A difference in the architecture of the surface membrane of normal and virally transformed cells. Proc. Natl. Acad. Sci. U. S. A. 62: 994.

27. Gold, P. 1971. Antigenic reversion in human cancer Ann. Rez'. Med. 22: 85.

28. Gold, P., and S. O. Freedmanl. 1965. Demonstration of tumor-specific antigens in human colonic carcinomati by immunological tolerance and absorption techniques. I. Exp. Mcd. $121: 439$.

29. Herberman, R. B. 1972. Serological analysis of cell surface antigens of tumors induced by murine leukemia virus. J. Natl. Cancer Inst. 48: 265.

30. Weksler, M. E. 1972. Response of normal and leukemic patients to lymphoblast-associated determinants. J. Clin. Invest. $51: 102 \mathrm{a}$.

31. Nilsson, K., G. Klein, W. Henle, and G. Henle. 1971. The establishment of lymphoblastoid lines from adult and fetal human lymphoid tissue and its dependence on EBV. Int. J. Cancer. 8: 443.

32. Gerber, P., J. Whang-Peng, and J. H. Monroe. 1969. Transformation and chromosome changes induced by Epstein-Barr virus in normal human leukocyte cultures Proc. Natl. Acad. Sci. U. S. A. 63: 740.

33. Nonoyama, M., and Pagano, J. S. 1971. Detection of Epstein-Barr viral genome in non-productive cells. Nat. New Biol. 233 : 103.

34. Gerber, P. 1972. Activation of Epstein-Barr virus by 5-bromodeoxyuridine in "virus-free" human cells. Proc. Natl. Acad. Sci. U. S. A. 69: 83

35. Hampar, B., J. G. Derge, L. M. Martos, and J. L. Walker. 1972. Synthesis of Epstein-Barr virus after activation of the viral genome in a "virus-negative" human lymphoblastoid cell (Raji) made resistant to 5-bromodeoxyuridine. Proc. Natl. Acad. Sci. U. S. A. 69: 78. 